Portland State University

PDXScholar

\title{
Exploring Strategic Strengths and Weaknesses of Retail Purchasing Groups
}

\author{
Erik Sandberg \\ Linköping Institue of Technology \\ Carlos Mena \\ Portland State University
}

Follow this and additional works at: https://pdxscholar.library.pdx.edu/busadmin_fac

Part of the Business Administration, Management, and Operations Commons, and the Operations and Supply Chain Management Commons

Let us know how access to this document benefits you.

\section{Citation Details}

Sandberg, E., \& Mena, C. (2015). Exploring strategic strengths and weaknesses of retail purchasing groups. The international review of retail, distribution and consumer research, 25(3), 276-297.

This Post-Print is brought to you for free and open access. It has been accepted for inclusion in Business Faculty Publications and Presentations by an authorized administrator of PDXScholar. Please contact us if we can make this document more accessible: pdxscholar@pdx.edu. 


\title{
Exploring strategic strengths and weaknesses of retail purchasing groups
}

\author{
Erik Sandberg and Carlos Mena
}

\section{Linköping University Post Print}

\section{Tweet}

N.B.: When citing this work, cite the original article.

This is an electronic version of an article published in:

Erik Sandberg and Carlos Mena, Exploring strategic strengths and weaknesses of retail purchasing groups, 2015, International Review of Retail Distribution \& Consumer Research, (25), 3, 276-297.

International Review of Retail Distribution \& Consumer Research is available online at informaworldTM:

http://dx.doi.org/10.1080/09593969.2014.982679

Copyright: Taylor \& Francis (Routledge): SSH Titles http://www.routledge.com/

Postprint available at: Linköping University Electronic Press

http://urn.kb.se/resolve?urn=urn:nbn:se:liu:diva-120956 


\title{
Exploring strategic strengths and weaknesses of retail purchasing groups
}

\author{
Retail purchasing groups consist of small, independent, specialised stores that \\ join together and collaborate on purchasing and other areas. In comparison to \\ large-scale corporate retail chains, often labelled mega-retailers, retail purchasing \\ groups are based on collaborative external integration between a central unit and \\ the independent, local dealers. The overall purpose of this research is to explore \\ the specific characteristics that underscore a retail purchasing group. The paper \\ has two research questions: (1) What are the strengths and weaknesses of a \\ supply chain structure based on external integration?, and (2) In what areas is the \\ purchasing groups' ownership structure particularly advantageous in comparison \\ to the mega-retailers' vertically integrated organisations? This exploratory \\ research is empirically grounded in a case study of two Swedish purchasing \\ groups. The paper argues that under certain market conditions, a decentralised \\ supply chain, which relies on collaborative external relationships, can provide a \\ competitive alternative to a more traditional centralised structure. The paper \\ elaborate three areas where the structure is particularly advantageous: (1) service- \\ based competition in an industry otherwise focused on cost leadership, (2) in- \\ depth understanding of local conditions and presence, and (3) the ability to \\ incorporate entrepreneurial strengths and innovations in the supply chain.
}

Key words: retail purchasing groups; competition; supply chain integration; collaboration; organisation

\section{Introduction}

In line with an end-to-end supply chain management approach, retailers have, in recent years, started to look beyond their own company walls to integrate the resources of their suppliers (Ganesan et al., 2009; Sandberg, 2013). Retailers have moved from simply placing orders to managing the processes from the source of delivery to the stores (Renko and Ficko, 2010). In this development, it is above all large-scale, international 
corporate retail chains, such as Zara, H\&M, IKEA, and TESCO that have been described as best practice in retail research (Abrahamsson and Rehme, 2010). These companies, often considered to have a so-called mega-retailer concept or "big-box format" (Sampson, 2008), have a supply chain orientation in which the entire chain is utilized to decrease costs and improve services (Abrahamsson and Rehme, 2010; Mentzer et al., 2001). The companies are often vertically integrated, i.e. the retail and wholesale function is conducted by the same company. In some cases, vertical integration goes even further, i.e. to manufacturing and product design and development. This vertical integration enables economies of scale and scope thanks to centralised purchasing, operations and decisions regarding product range, inventory levels, storage and transportation. Most retail sectors have in recent years due to the rise of multinational mega-retailers seen considerable cost reductions and low cost-based competition as a result of the mega-retailer model.

Retail purchasing groups offer an alternative business model, which consists of small, independent, specialised stores that join together and collaborate on purchasing and other areas, such as operations, management, financing, advertising and marketing (Chen and Roma, 2010; Walker et al., 2006; Zentes and Swoboda, 2000). Purchasing groups exist in a variety of retail sectors, such as food, furniture, and electronics (Chen and Roma, 2010) all around the world (e.g. Hernandez-Espallardo, 2006; Zentes and Swoboda, 2000). The main objective for companies joining a purchasing group is to increase their bargaining power and achieve lower purchasing prices (e.g. Essig, 2000; Hernandez-Espallardo, 2006; Walker et al., 2006; Zentes and Swoboda, 2000). However, management, ownership, and product range decisions, stay at a local level and thus their business model is fundamentally different from the mega-retailers. In 
essence, retail purchasing groups are based on collaborative external integration between a central unit and independent, local dealers.

As a consequence of the different ownership structure, retail purchasing groups cannot just imitate the mega-retailer concept in all aspects. Another type of supply chain effectiveness must be created. Empirically based on two case studies of Swedish purchasing groups, the overall purpose of this research is to explore the specific characteristics that underscore a retail purchasing group. The paper has two research questions: (1) What are the strengths and weaknesses of a supply chain structure based on external integration?, and (2) In what areas is the purchasing groups' ownership structure particularly advantageous in comparison to the mega retailers' vertically integrated organisations?

The remainder of this article begins with a literature review on purchasing groups, some theoretical underpinnings, and strategic strengths and weaknesses expected from a purchasing group organisation. Thereafter the methodology is presented followed by a within-case analysis of each case company. The findings are further interpreted in a cross-case analysis that is ended with propositions. Finally, conclusions, limitations and further research are discussed.

\section{Literature Review}

\subsection{What is a purchasing group?}

Although purchasing groups have a long history in practice, the terminology is not yet fully formalised (Tella and Virolainen, 2005; Essig, 2000). The content of a purchasing group spans from informal, simple sharing of purchasing information to formally organised long-term collaboration (Schotanus and Telgen, 2007). Perhaps the most common place where purchasing groups are established is in the public sector (Essig, 2000; Schotanus and Telgen, 2007; Walker et al., 2006). As a common, general term for 
the phenomenon, Essig (2000) uses "pooled purchasing", and outlines the different terms used in different types of companies. According to Essig (2000), another term for purchasing groups in the public sector is "cooperative purchasing", whereas purchasing cooperation between industrial companies is called "consortium purchasing". Joint purchasing among industrial companies or units that are not independent is commonly labelled "group purchasing". Among retailers the most frequently used term has been "buying offices" (Essig, 2000), but also other terms such as "group buying" have been used (e.g. Chen and Roma, 2010). Apart from the type of company involved (public sector, industry or retailer), the use of the term also depends on the independence among the participating companies and the formality of the cooperation (Essig, 2000; Schotanus and Telgen, 2007). Some similar terms and their definitions are shown in Table $1^{1}$ :

Table 1: Definitions of purchasing groups and related terms

\section{Please insert Table 1 here}

The retail purchasing group, as it is defined in this research, consists of small, independent, specialised stores that join together and collaborate on purchasing and other areas. Vertical as well as horizontal relationships play a major role in the supply chain of a retail purchasing group. As indicated in the introduction and illustrated in Figure 1 below, characteristic for a retail purchasing group is the external, vertical collaboration between a central business unit on the one hand, and the independent

\footnotetext{
${ }^{1}$ For a more detailed overview of different terms and definitions, see Essig (2000).
} 
dealers on the other hand. Furthermore, retail purchasing groups include horizontal collaboration among independent, local stores. The arena for communication and collaboration between the independent stores is mainly the centralised unit. Legally, the independent dealers could jointly own the central business unit, thus being the owner as well as the customer to the central unit at the same time.

Figure 1: A retail purchasing group in a supply chain (Source: The authors)

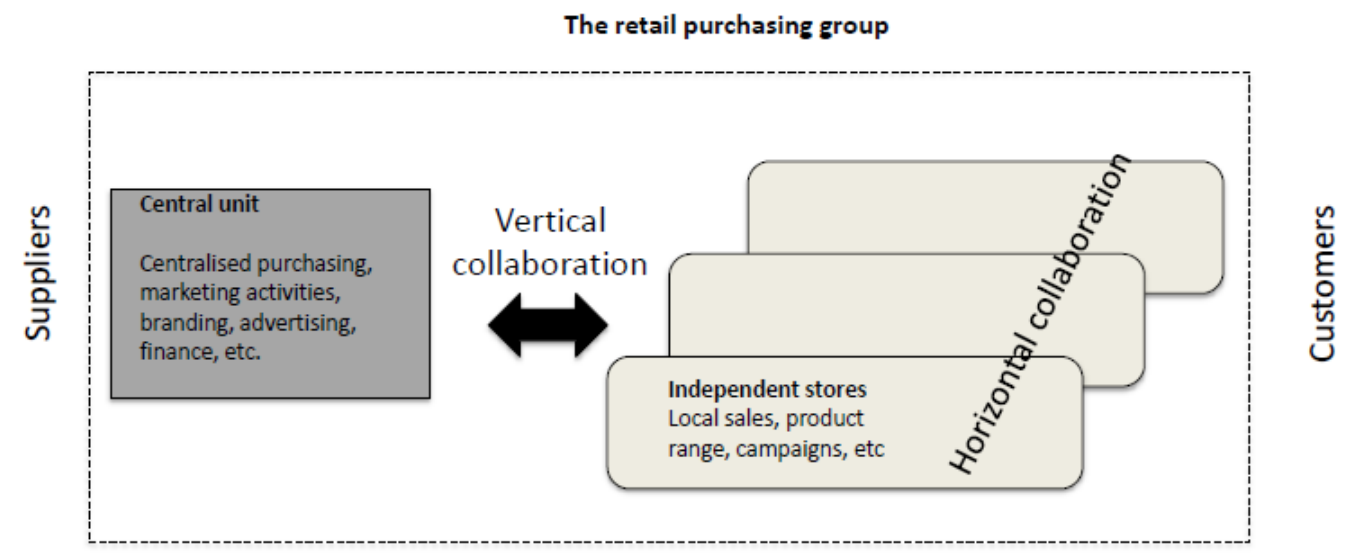

Figure 1: A retail purchasing group in a supply chain

\subsection{Theoretical underpinnings of the research}

This research is grounded in two distinct but compatible organisational theories:

Transaction Cost Economics (TCE) (Coase, 1937; Williamson, 1975; 1979) and the Resource-Based View (RBV) (Wernerfelt, 1984; Barney, 1991; Conner, 1991; Peteraf, 1993; Barney and Clark, 2007). TCE centers on the question of the boundary of the firm 
and how these boundaries are shaped by the cost of transactions, also known as coordination costs. According to TCE, there are three facets of transactions that can be used to establish the most cost efficient boundary of the firm: uncertainty, frequency and asset specificity (Williamson, 1975; 1979). The theory distinguishes three types of supply chain governance structures: hierarchies (produced in-house), markets (boughtin), and hybrid structures or collaborative alliances (Williamson, 1975; Williamson, 2008). Whereas the mega-retailers are built on a supply chain structure with in-house hierarchies, TCE is useful when considering purchasing groups because it helps to explain the circumstances under which market and hybrid structures can be advantageous from a cost perspective.

TCE has been criticized for being overly focused on costs and risks, ignoring other aspects of business transactions such as value, innovation and flexibly (Perrow, 1986; Simon, 1991; Goshal and Moran, 1996). To address this limitation we find support in the RBV literature. The main argument of RBV is that organisations have resources, and that those resources that are valuable and rare, can allow organisations to attain competitive advantage (Barney, 1991). Furthermore, if these resources are difficult to imitate, transfer or substitute, they can lead to sustainable competitive advantage (Barney, 1991). A development of RBV proposed by Teece et al. (1997) argues that dynamic capabilities allow firms to build, integrate and reconfigure internal and external competences; i.e. enabling them to adapt.

TCE and RBV provide different perspectives on the boundaries of firms, however, they have been found to be complementary by a number of authors who argue that neither theory can fully explain firm boundary decisions (Combs and Ketchen, 1999; Jacobides and Winter, 2005; Madhok, 2002; McIvor, 2009; Vivek et al., 2008;). Combs and Ketchen (1999) go as far as arguing that neither of these theoretical lenses can provide a 
comprehensive explanation of collaboration, and that both are required to study interorganisational phenomena. As McIvor (2009) contends, TCE can help understand the most efficient governance structures through economic transactions, while RBV can be used to identify those resources, particularly relational resources (Dyer and Singh, 1998), that can lead to sustainable competitive advantage. For these reasons we decided to underpin our research with both theories.

Crucial for this research, as it represents one of the major characteristics of a purchasing group, is supply chain integration and collaboration. Although often anchored in TCA or RBV, there seems to be a great deal of inconsistency and ambiguity around the meaning of these concepts. As Pagell (2004) asserts, the concept of integration might be familiar to most supply chain researchers, but there is no widely accepted definition of the term and the actual conceptualisations vary a great deal. For instance, Lawrence and Lorsch (1967) take an intra-organisational perspective on integration and define it as "the quality of the state of collaboration that exists among departments that are required to achieve unity of effort by the demands of the environment." (Lawrence and Lorch, 1967, p. 11). On the other hand Barratt and Oliveira (2001) propose an interorganisational view, arguing that integration occurs when two or more companies share the responsibility of exchanging common planning, management, execution, and performance measurement information. Also when it comes to collaboration, the literature is vast and several definitions exist. One of them is "working jointly to bring resources into a required relationship to achieve effective operations in harmony with the strategies and objectives of the parties involved, thus resulting in mutual benefit" (Humphries and Wilding, 2004, p 1109). An advantage of this definition is that it includes collaboration inside as well as between independent organisations, i.e. external as well as internal. 
To structure the literature, Anderson and Narus (1991) argue that relationships could be placed on a relationship continuum, ranging from arms-length, transactional relationships, to collaborative and vertically integrated relationships (Mena et al., 2009). In this continuum, inter-organisational relationships are placed on the "adversarial" side of the continuum, whereas intra-organisational relationships are placed on the "collaborative" side of the continuum (Mena et al., 2009). This positioning assumes that internal relationships are more collaborative than external ones. An explanation for this assumption may be that research in the area is, to a large extent, based on the transaction cost economics (TCE) framework (Chen et al., 2009), where vertical integration is considered to reduce transaction costs associated with uncertain market exchanges (Williamson, 1985). Thus, TCE suggests organisational governance as a means to control opportunistic behaviour (Williamson, 1985). However, there are other mechanisms to cope with uncertainties in the supply chain. From a collaboration perspective, mechanisms such as trust, commitment, coordination and joint problem solving are possible (Wang and Wei, 2007).

There are some studies that question the common assumption that intraorganisational relationships involve closer collaboration than external ones. For instance, Mena et al. (2009) present empirical data from two case studies, where the degree of collaboration in intra- and inter-organisational collaboration is compared. The findings conclude that the inter-organisational relationships investigated were actually considered to be more collaborative by the respondents. According to Mena et al. (2009) there is not always a congruency between organisational governance structure and the level of integration and collaboration among supply chain partners. In a similar vein, Chen et al. (2009) assert that "many managers report that it is easier for buyers to integrate with their suppliers and for logistics managers to integrate with their 
customers than it is for either group to integrate within the firm across various functional areas" (Chen etal., 2009, p. 66).

To associate external relationships with a lower degree of collaboration and internal relationships with greater collaboration appears problematic. Chen et al. (2009) discuss supply chain integration, and argue that internal and external integration should be treated as different concepts due to the many differences in terms of organisational ownership, structure, policies and values. Thus, there may not be a continuum that incorporates internal as well as external collaboration. By separating the constructs of collaboration and supply chain governance, it is possible to argue that vertical integration, as practiced by mega-retailers (which results in intra-organisational relationships with the stores), does not automatically entail more collaborative relationships than those maintained by retail purchasing groups.

\subsection{Strategic strengths and weaknesses of retail purchasing groups}

Despite the extensive presence of retail purchasing groups, they have received limited attention from the research community (Essig, 2000; Tella and Virolainen, 2005). One area in particular that has remained under-researched is the competitive base of purchasing groups when compared to mega-retailers and other vertically integrated retail chains. Fundamental for competition, and hence a foundation for strategic strengths and weaknesses, is the creation of economies of scale and scope. In fact, a major driver for the existence of retail purchasing groups is to create economies of scale and scope in above all purchasing, but also other company functions such as merchandise management, accounting, financing, personnel training and education (Zentes and Swoboda, 2000). According to Chandler (1990) economies of scale could be gained by producing or distributing an increased volume of a unit, which results in a reduction of unit cost. Economies of scale exist when the long-term average cost per 
unit of output decreases as the capacity increases (cost increases in a slower pace than the increase in capacity).

According to Panzar and Willig (1981) economies of scope occur when it is less costly to combine two or more product lines in one firm than producing them separately. Chandler (1990) widened their argumentation outside the production field and argued that economies of scope arises when a unit produces or distributes more than one product at a lower cost than a single product. Thus, economies of scope exist where the same equipment and resources can produce multiple products or services in combination at a lower cost than separately (Goldhar and Jelinek, 1983).

Economies of scale as well as scope are often discussed together with degree of centralisation, assuming that a greater centralisation brings further economies of scale and scope. Chow et al. (1995) discuss two dimensions of centralisation: the first dimension is referred to as concentration - the extent to which the power to make decisions is concentrated in the organisation. In a retail purchasing group this concentration is considerably less than in a vertically integrated retail chain due to the freedom of making choices about e.g. product range and marketing campaigns. Overall, this freedom hence hampers decision making concentration, which in turn obstruct creation of economies of scale and scope.

Chow et al.'s (1995) second dimension refers to the proximity to the top - the hierarchical distance between logistics decisions-makers and senior executives, who make decisions on an organisation wide basis. This points at the importance of connecting functional areas to management, e.g. such as retail shop design, product range, and store concepts. In retail purchasing groups, an additional level is added in the supply chain, which results in more complex and longer decision-making processes (Zentes and Swoboda, 2000). 
From a centralisation point of view the retail purchasing group concept seems to be less preferable than a mega-retailing concept. However, although economies of scale are an important factor for supply chain efficiency there are several obstacles with a too narrow focus on economies of scale, sometimes there are present what may be referred to as diseconomies of scale. Pil and Holweg (2003) highlight four areas where smallscale operations may be advantageous;

(1) proximity to local knowledge networks,

(2) responsiveness towards customers,

(3) development of human capital in the form of broader responsibility areas for younger management cohorts, and

(4) exploration and testing of new technology.

Although these areas may be acknowledged as important and relevant for most companies, they are often hard to quantify in monetary terms. Perhaps this is the reason why large-scale operations are often prioritised (Pil and Holweg, 2003). For retail purchasing groups these four areas are relevant to examine further. It is likely that independent dealers with external collaborations may utilise these possibilities better than a vertically integrated retail chain. For instance, in a less centralised and rigid supply chain, there may be better opportunities for the creation of local relationships with customers as well as (local) suppliers (Hernandez-Espallardo and Navarro-Bailon, 2009), and lower transaction costs due to more rapid, efficient purchasing process (Tella and Virolainen, 2005; Walker et al., 2006).

\section{Methodology}

This research is based on an exploratory multiple case study (Ellram, 1996; Yin, 2003) of two Swedish purchasing groups, operating in the retail sectors of (1) home 
electronics and (2) appliances. The retail groups investigated in this research function as examples of retail purchasing groups that have started to re-evaluate their strategic position in the market and wish to avoid imitating the mega-retailers. Both companies are having, similar to the mega-retailer concept, a relatively extended scope of functions managed by a central unit. However, they accept that they will never be able to compete on the same basis as the mega-retailers: they will always have local, strong store owners that are not willing to leave all decisions to a centralised management.

\subsection{Case Selection}

The selection of cases started with a workshop involving 20 retail purchasing groups in Sweden. To identify suitable case companies, a survey was sent out to the participants, from which 12 answers were received. Based on the results of the survey, which mainly included topics related to purchasing/supply, product range, and distribution, the two cases for this article were identified based on the following criteria:

- They both have a relatively high degree of centralisation. This means that, apart from being based on external relationships instead of vertical integration, they are similar to the mega-retailer concept in other aspects (this makes them easier to compare). Signs of their high degree of centralisation included:

- They indicated that logistics and distribution development is just as important as purchasing and marketing issues for the purchasing group and should therefore be handled centrally.

○ They had a centralised IT system, including e.g. ordering and accounting functions.

○ They had a central warehouse (an inventory point managed outside the independent retailers' "own" company). Out of the 12 purchasing 
groups, these two companies were the only ones with a centrally managed warehouse.

- A second criterion was that both groups have over a long time shown themselves to be profitable in two retail sectors that are facing very fierce competition. A sign of this competition is the fact that as a result of focus on cost competition, one of Sweden's largest mega- retailers of home electronics and appliances was declared bankrupt in 2011. The two case companies are relatively small in comparison to their international mega-retailer competitors, but have despite this been able to stay successful on the market with a service-oriented strategy. Thus, the two case companies seem to have a competitive business model vis-à-vis the mega-retailers.

To ensure external validity (Gibbert et al., 2008; Yin, 2003), the cases were chosen based on a theoretical sampling approach (Eisenhardt and Graebner, 2007), with the criteria as shown above. The chosen companies provide the researchers with a rich data set that has helped to expand knowledge about the strengths and weaknesses found in a purchasing group concept.

\subsection{Data Collection}

Together with the research team involved in the research project, a general interview guide was developed based on the research questions. The interview guide, designed as semi-structured interviews with open-ended questions, included five areas (the full interview protocol is included in Appendix A):

(1) General information about the group

(2) Organisation

(3) Logistics operations and organisation 
(4) Advantages and disadvantages of a purchasing group concept

(5) Future development of the group

A first round of semi-structured interviews with each purchasing group was conducted with the informant of the survey. Thereafter, after the initial interview and information about the research project, the interviewees helped to identify further people to interview. In common for all interviewees is their managerial position (see Table 2). The interview guide was slightly modified depending on the focus of the particular interviewee. Each interview lasted 1-2 hours. In total 8 interviews were conducted during a period of 2-3 months. The first visit also included an on-site visit at the central warehouse, enabling more specific questions about the logistics operations. As such, the total number of people working at the central units is rather low, and each person is well informed about the entire business, i.e. a purchasing manager is well aware of, and is able to respond also to marketing considerations of the company. Therefore four people at each company were found to cover the questions in a satisfactory way, i.e. the researchers experienced what Eisenhardt (1989) refers to as theoretical saturation.

Table 2: Titles of interviewees at the case companies

Please insert Table 2 here

All interviews were transcribed and the data from the interviews were accompanied with secondary sources of information. These sources include annual reports, newspaper and magazine articles, and consultancy reports.

To increase internal validity (Yin, 2003) of the study, the data were structured and presented in two areas: strategic market position and organisation. Suitable citations 
were selected based on the research interests (research question) as a means to strengthen the argumentation in the presented data (Stuart et al., 2002). Analysis thereafter followed the procedure described in Yin (2003) using within-case analysis followed by a cross-case comparison. To decrease complexity in the analysis process, the authors have, for instance, tried as much as possible to (1) separate the within-case analysis from the cross-case analysis, (2) establish the much-discussed "chain of evidence" (e.g. Gibbert et al., 2008; Yin, 2003) between interview protocols, extended case descriptions, and analysis as a means to ensure construct validity, (3) structure facts in tables, and (4) explicitly discuss with each other what underscores (supports) a certain finding. Furthermore, reliability has been enhanced by purposeful descriptions of our cases and presentation of our analysis, enabling critical understanding and scrutinising by the reader (Stuart et al., 2002).

\subsection{Data Analysis}

The analysis procedure started with the within-case analysis, which provided us with an in-depth understanding of the groups' specific market positioning strategies and organisational design, in terms of centralisation and decentralisation, as well as aiding our understanding of industry- and company-specific peculiarities (Stuart et al., 2002). In the following cross-case analysis the focus was on answering the two research questions, by comparing and contrasting the findings from both cases. Through an iterative search process, key strategic strengths and weaknesses based on the purchasing group's strategic market position and organisational design were identified. These findings were aligned and developed based on the theoretical underpinnings of TCE and RBV that is applied in the paper.

\section{Within-case analysis}

In this section the within-case analysis of the two purchasing groups, referred to as 
"Group A" and "Group B", are presented. As a means to capture the strategic strengths and weaknesses of collaborative external integration, as is the basis for retail purchasing groups, the empirical data is presented around the case companies' strategic market position and their organisations. The strategic market position is imperative to understand how the company achieves competitive advantage. In a simple form, this could be described in terms of cost leadership and differentiation, as presented by e.g. Porter (1985). The organisation, in turn, constitutes the tool for how to achieve the desired market position. Thereafter strengths and weaknesses related to the interorganisational setup are presented.

\subsection{Group A}

\subsubsection{Market position}

With a long history in services of electronic devices, Group A had in 2012 an annual turnover of $€ 108$ Million. The group today mainly consists of 247 individually owned stores organised in two chains specialising in home electronics, and one chain specialising in mobile phones. The central unit of the purchasing group is an independent company marked on the Stockholm stock exchange market. In this company property rights, brands, central warehouse, etc are owned. Local store owners, of which many are holding shares in the company, owns in turn the stores and are legally independent companies. Overall, the relationship between the central unit and the local store owners are long term, and regulated with long term contracts concerning e.g. marketing activities, and financial support. In addition, the stores, depending on their size and what chain they belong, are restricted to buy a certain share of their total sales through the central unit company, normally around 70-80\%. Products not purchased via the central business unit are often purchased via other local distributors on direct demand from end customers. Although the central unit offers a long range of 
products and brands to competitive prices, it is seen as an important part of the customer offering to also be able to provide other brands if the customer demands it.

In terms of market position, the stores in the group could best be described as the service-oriented alternative on the local market(s). Competing in first hand on the local market in small to medium sized stores, the stores are expected to be positioned as a high-end service alternative, selling premium brands accompanied with extensive warranties and installation services. The stores are known to have skilled personnel that are able to demonstrate advanced, high-end products. In fact, also the suppliers have recognised the skilled personnel as a crucial advantage for their high-end products. The knowledge of the staff and commitment to the products attract the suppliers in the sense that they gain a partner who is able to sell their high-end products. For instance, when LED TVs were introduced on the Swedish market some years ago, one of Group A's chains became the dominating sales channel, despite their relatively small market share.

\footnotetext{
"They [the store owners] are nerds...They love their work and the products they are selling. They know everything about them. Here we have an advantage. The suppliers prefer to sell their high-end products in our market channel. Then they know that the brand is well preserved." (Chain Manager Y, Group A, author's translation)
}

The proximity to the local market, and knowledge about the local customers and conditions, is considered as a key element of the stores' market position. Recently a chain manager in one of Group A's chains launched the slogan "Go local" to express their focus on locally oriented business. The focus on local markets is seen in the business plans and market analyses; whereas the standard procedure in most retailers in the sector is to develop business plans and conduct market analyses on larger regions, Group A conducts specific market analyses for each and every single store. 
The combination of closeness to the customers, skilled personnel, and the technological development of the products is nowadays a profitable one, and may in the future be an even more promising business concept. The technological development of the products has made it difficult for many customers to install, repair, and utilize the whole potential of electronic devices and the need for personal assistance is increasing. The service part of the business may become even more important in the future:

\footnotetext{
"The technology does not become easier. No one can beat us [our stores] when it comes to knowledge in technology. It could be that in 15 years you buy your TV somewhere else but it is our store that comes and installs it, puts an antenna on the roof, and makes sure you have the right connection to your network, etc. Our competitors will never beat us in that area and this is something we will take advantage of."

(Chain Manager Y, Group A, author's translation)
}

\subsubsection{Organisation}

In the heart of the group's supply chain there is a central warehouse, operated by the central unit company. All products are distributed from suppliers via a central warehouse for further transportation on to the stores. Apart from the central warehouse and purchasing function, the group centrally also provides a number of services for store owners, such as IT support, accounting and a back-office sales support team. To further enhance economies of scale and scope in the central warehouse, the group also acts as a third party logistics provider offering an extensive variety of logistics services to, among others, an Internet-based retailer of multimedia products.

The business model of Group A is based on the idea that the stores are about to remain local and at the same time access advantages connected to the membership of a larger purchasing group. The organisational structure with external, collaborative integration is considered to be the instrument where this paradox could be balanced. A 
key organisational task - and challenge - acknowledged by the group management is therefore to manage and control this paradox.

As a result of the business model and organisation, the management at Group A has taken a supportive role in the supply chain, not making decisions concerning e.g. price or product range. Innovation in the supply chain is also to a large extent driven by initiatives of individual store owners. One example is the continuous development of the IT system used by the store owners in the group. Ideas for development of new applications and other improvements are often grounded in needs and requirements from local store owners. Due to long term relationships and formalised user groups where feedback can be received, the central unit level that develops the IT system continuously get feedback on how to further improve the system. Individual local store owners also becomes an important platform for testing and verifying new applications of the system.

From their central position in the supply chain, Group A has, to a large extent based on the existence of a central warehouse, launched the concept "Welcome backstage", where the central unit company operates as a centralised distributor:

\footnotetext{
"We are attractive thanks to our machinery. What we do we label 'Welcome backstage'. We shall be backstage. The whole idea came when we were attending a Bruce Springsteen concert. Just 15 minutes after Springsteen had finished playing and the entire machinery had been working, loudspeakers were dismantled, floors rolled up, etc., and two hours later a number of trucks were on their way to the next place... We shall be backstage, and the dealer shall be Springsteen. He is supposed to be the star in the store. Everything else around should just work perfectly fine." (Chain Manager Y, Group A, author's translation)
}

\subsubsection{Perceived Strengths}

The structure relying on collaborative external integration renders strengths as well as weaknesses according to the interviewees in the company. Well aware of their specific 
organisational design, major advantages pointed out by the informants are the ability to offer a true local product range and pricing, adjusted by the store owner himself also working in the store. A flexible view on the pricing and proximity to owner makes the store adaptable to changes in the local environment. In comparison to other retail chains in the neighbourhood, Group A's stores have often been able to take advantage of more rapid response to price changes than competitors.

As a means to offer the customers a local alternative, several informants recognise the independent dealers as the group's major competitive weapon. The dealers are described as entrepreneurs and "nerds", with a great passion for their work and the products they are selling. Family owned, locally anchored business men, sometimes for generations, are considered to be the best representatives for meeting the customers. The ownership structure of the group is here considered as a strength, although somewhat unusual and managerial demanding as it requires commitment and long-term planning:

"This is a complex business model and above all rather unusual. But if we are able to come through and implement it, we have a model that is hard to imitate." (Chain Manager X, Group A, author's translation)

The local dealers with their own stores are also recognised as a key competitive advantage in the sense that the individual stores will be very loyal and have an astonishing capability to survive in the ever-changing competitive landscape:

"We can live on bread and water for a long time since we have the local [independent] dealers. The store is their life."

(Chain Manager X, Group A, author's translation)

\subsubsection{Perceived Weaknesses}

According to the group management, the external collaborative integration fits well 
with the store's position on the local markets. However, as one of the informants acknowledge, the organisational design also inhibits effective competition based on other market positions than the selected one. Group A is not able to compete on large volumes and price at first hand. In fact, in contrast to their mega-retailer competitors, their supply chain organisation with independent, profit making dealers inhibits such competition:

\begin{abstract}
"If you choose to compete based on volumes you must compete with size. And if you do not own your stores this is difficult. Elgiganten [a mega-retailer competitor] doesn't make money in the stores - it's all about volumes and making the money centrally on purchasing and economies of scale in logistics. A single store may even have negative results and despite that be applauded thanks to large turnover... We do not take this type of fight."
\end{abstract}

(Chain Manager X, Group A, author's translation)

The fact that the final decision of product range is left to the individual stores means a larger product range with relatively small volumes needs to be managed. In a negotiation phase, the purchasing organisation may sometimes be squeezed between the stores' individual wishes for products and brands, and the suppliers' knowledge about the fact that the final call about product range is taken not by the purchasing organisation at the group level, but at the individual stores. As stated by the purchasing manager, the locality thus comes with a price: more complex and costly purchasing conditions.

Overall, Group A constitutes an example of the complexity of a structure with collaborative external integration in comparison to vertical integration. The structure of Group A contains several managerial challenges and the process of exploiting the full potential of the concept is still in its infancy: 


\begin{abstract}
"Now we are two tiers in the same company. I, fairly new in this company, can see that they [the purchasing group] are working like they were one company but they are not. Of course it is good if we synchronize ourselves, however it is also positive if we could find the dynamism of not being one, single company... I consider it as a strength to not own our stores. However, it takes a while before you can have such a discussion internally and I do not think we are there yet." (Chain Manager X, Group A, author's translation)
\end{abstract}

\title{
4.2 Group B
}

\subsubsection{Market position}

Group B is a purchasing group founded in 2004 by two chains of specialised stores in the sector of appliances and electronic devices. Today, 450 member stores organised in five different chains jointly owns the shares in the company that constitutes the central unit of the business group. In 2012 the members of the group together had a turnover of $€ 270$ Million. The chains are all slightly different when it comes to product range and targeted customer segments, and have different degrees of independency for instance when it comes to decision rights of the product range and purchasing from other companies than the jointly owned central unit company. All five chains in the group could be characterised as specialist stores, with great knowledge about the products and an extensive service offering, including installation, financial services, extended warranties, etc. Overall, services rather than low price dominate the chains' market positions. It is clear that in an international market, there are always international chains that will have larger volumes and thus have a price advantage:

\footnotetext{
"Independent of what we do we will never reach the same volumes as Mediamarkt [a mega-retailer competitor]. This means that we will never be able to compete based on price. We have to offer something more. And that is what we try to do with our stores. They ARE something more, and give the customers better value. And for our strategy, it becomes crucial to have a look at what more we can offer." (CFO, Group B, author's translation)
} 
The group is continuously looking to support and strengthen the chains' service oriented position in the market. There is a general recognition in the company that the development in the market will further favour companies with a strong service profile. Apart from the fact that the more the competitors focus on price, the larger the space left for actors with a differentiation profile, there is also a growing need for service among customers. One example is the growing trend in fully integrated, built-in appliances. This leads to a more complicated purchase and installation for the customers, where the relative importance of price is downplayed in favour of service aspects.

One example of a recent development of the service offering is the foundation of a joint service company for the chains, which will enable control of services to customers, e.g. repairs and other maintenance issues. In comparison, competitors are normally in the hands of general service and repair companies, where the origin of purchasing place is not important. With an 'own' service company, the group will be able to control, improve and develop the service offering in the future. This new subsidiary is to a high extent a result of innovation at the store-level in the supply chain. The development, and wish for a national service subsidiary, has been driven by local, similar initiatives by some of the local store owners. These local initiatives of an extension of maintenance and repair services has been brought to group level where the learnings have been accumulated and forms the basis for the national service subsidiary that now is launched.

The service and knowledge profile in the market have also been shown to be beneficial toward the suppliers. Several suppliers deliberately select the chains in Group B as their primary market channel, in particular for their premium products. These products need to be sold together with knowledge and personal assistance, which is what is offered by the stores in the group. 


\subsubsection{Organisation}

The primary organisational task at group level is to purchase all appliances from suppliers and offer these products to the member stores. In total, Group B stores and handles about 500 different articles in the appliances assortment, and about 25,000 electronic devices. At the heart of Group B's operations there are two central warehouses, one for appliances and one for electronic devices. To these warehouses all appliances and electronic devices are taken from suppliers, enabling large volumes to be bought and transported in the supply chain. Apart from purchasing and the central warehouse function, Group B also handles the centralised functions such as administration, advertising, IT and education.

The overall task at a group management level is to create economies of scale and scope when possible, e.g. in purchasing, logistics, marketing activities, accounting, etc. Meanwhile the chains and in particular the individual stores will be able to focus on sales and local marketing activities:

"The chains and stores will continue to work with their core businesses. We will stand there behind them and take advantage of this volume and organisation we have built up centrally."

(CFO, Group B, author's translation)

Important part of the sales and local marketing activities is the management of the product range, which today is decided by the local stores. Although the individual stores are legally restricted to purchase a certain sales volume (in percent of their total sales) from the central unit company, the product range is complemented with other brands and products from other suppliers. Giving the dealers this opportunity is seen as a tool for creating and driving the central unit's competitiveness vs. other procurement alternatives for the stores, but above all it is a possibility for adjustments to local customer demands as a means to increase the local stores' competitiveness. 
In the group there is a general trend toward more centralization. Since the group was founded there has been a continuous development of services offered centrally toward the stores, which has led to a centralisation of more and more functions. Several interviewees appreciate the fact that the more the functions are centrally organised, the easier it becomes to add additional functions to be managed centrally. A recent centralisation was made last year when the printing of all advertising material was brought in-house, i.e. became a centrally managed functional unit.

\subsubsection{Perceived Strengths}

Group B holds the stores and their owners' entrepreneurship as their major strategic strengths and competitive weapon. Although a strong centralised unit with full responsibility of many functions, the organisational structure based on collaborative external integration gives the independent decentralised stores a crucial role in the business model. These stores are often managed as a family business with a strong local presence; in some cases the store has been established in the town for more than 50 years. The independence is considered to be the major reason for the entrepreneurial spirit that characterise the store and the store owners. Overall, the independent store owners outweighs the disadvantages of the purchasing group concept according to the CEO:

\footnotetext{
"In some instances perhaps it would be advantageous if we were a wholly-owned company [as the mega-retailers]. At the same time it is, however, an advantage to work with independent dealers because there is such an impact and entrepreneurial spirit in what they do. It may sound like nonsense talk, but if we really decide to do something we will do it! There is a power that I do not think you can get with store managers who are only 24-25 years old. This, in fact, outweighs the disadvantages. But it represents some pedagogical challenges and some tactics." (CEO, Group B, author's translation)
} 
Related to the entrepreneurial spirit and focus on local conditions and an understanding of customers' needs, goes hand in hand with a high level of knowledge of the staff. As commented by one of the informants, the long term commitment and ownership structure enables knowledge to be built in and utilized in the store for a long period of time. This in turn is according to the interviewee a prerequisite for qualified services. Although new products and new technology is constantly changing, many basic learnings about the industry are the same.

An organisational design with collaborative external integration is often considered to be a managerial act of balance between centralisation and decentralisation, this is also the case for Group B. Interestingly however, the interviewees also witness that there are occasions where centralisation and decentralisation complement each other. For instance, when it comes to marketing activities, these are launched at three levels within the group. First, a marketing campaign can be initialized by the purchasing department together with the product advisory board; second, a campaign can be launched by a single chain (often together with the purchasing department; and third, individual campaigns at store level occur on a continual basis (which is encouraged at a group level). Thus, central initiatives are mixed and complemented by local campaigns, rather than being at odds with each other.

\subsubsection{Perceived Weaknesses}

The management of Group B points at two major weaknesses with their present organisational design. First, the purchasing organisation suffers from lacking control of product range management. In general, as the final decision about the assortment is made by the local store owner, the centralised purchasing managers sometimes find themselves constrained in their work. More specifically, examples of problematic situations occur when there is an opportunity to purchase large volumes to a low price 
in one of the suppliers' campaigns, or when store owners prefer similar products of different brands and/or quality. Decision lead times could also be prolonged due to extensive product meetings internally in the group where purchasing managers and representatives for the individual stores and chain managers participate.

A second weakness related to the one described above, is the need for management of several chains. The five chains are having an overlapping product range but are in some circumstances very different and are partly targeting different customer groups on the markets. Administrative efforts and marketing activities are two examples of activities that drives overhead costs that are disproportionate to the benefits of having five separate chains. As a means to address this problem, the group has recently started a work where the five chains are expected to be two in the future.

\section{Cross-case analysis and discussion}

Operating in fiercely competitive retail sectors, the two case companies showcase a different business model compared to those of the mega-retailers'. Common to both case companies is a competitive market position based on extensive service-offering rather than low price. The small- to medium sized stores are anchored in the local community, sometimes with the same family as owners for generations. Without ambition to grow in size into other geographical regions, it is considered better being a large player on the small, local market, rather than a small player on a national market. Another key feature important for the market position taken is the store owners' entrepreneurial approach and commitment and knowledge about the products they are selling. Both case companies clearly stress entrepreneurship and product knowledge as one of their key competitive weapon and a foundation for the group's market position.

In terms of organisation, both groups have had a time of reorganisations to better exploit and manage their strategic strengths. The within case analyses reveal that the 
collaborative external integration structure of a purchasing group means that a selection of functions and activities are to be selected and managed centrally, whereas others are given to the local store owners. Centralised functions in the case companies are typically purchasing, logistics, IT, and accounting. Important decentralised functions and activities discussed in the case companies are pricing and product range decisions. Marketing and advertising activities are normally considered as shared responsibility where centralised, national campaigns are complemented by local initiatives.

The within-case analysis identified several similar strategic strengths and weaknesses as a result of the market position and the organisation. The most important strategic strengths stressed by the informants at the case companies are:

- The ability to offer a true local product range that is combined with a local pricing strategy

- An entrepreneurial atmosphere that fosters and encourages local initiatives

- High product knowledge and competence of the staff, which enables e.g. ability to demonstrate and sell advanced products in the store

In terms of strategic weaknesses, the case companies are despite recent reorganisations, still struggling with organisational challenges. The act of balance between centralisation and decentralisation is considered as major managerial challenge. More specifically, the case companies address weaknesses related to:

- Inability to compete based on low price due to less purchasing volumes and control of product range.

- Complex and time-consuming decision lead times which inhibits rational purchasing decisions.

- Management of (too many) chains with slightly different market positions. 
Based on the empirical evidence, we propose three areas where the supply chain structure of retail purchasing groups can build competitive advantage: service-based competition; local presence; and entrepreneurship and innovation. Below we construct propositions around each of these three areas.

\section{Service-based competition}

In terms of strategic position, the chains in the case companies have a strong service profile in the market and differentiate themselves from the low-cost competition that dominates the home electronics as well as the appliances sectors. The focus on price in the sectors leaves a large space for alternative ways to compete, such as having an extensive service offering. Recent examples of the service development in the two case companies are the creation of a new subsidiary taking care of maintenance and repairs, and a new back-office sales organisation. In both retail sectors is also recognised a growing need for extended services due to more advanced products, which further vitalizes and feeds the service development.

Although other types of retailers may compete based on services, the purchasing group concept enables a large degree of freedom for individual, local designs for value creation. This freedom, in combination with knowledge about the local market and a strong entrepreneurial spirit at store level, is the foundation for the continuing development of the service offering. We propose that:

Proposition 1: Retail purchasing groups allow retailers in their network to develop a service-based proposition in industries that are normally focused on price. 
From an RBV perspective (Barney, 1991; Barney and Clark, 2007), both knowledge and freedom to adapt to local market conditions are resources that firms operating in the purchasing groups can deploy in order to compete in the marketplace. These resources and the development of more advanced service offerings is not unique to retail purchasing groups, however, it can be argued that these are more difficult to imitate, transfer or substitute by mega-retailers who have more rigid and standardised processes (Abrahamsson and Rehme, 2010; Sandberg, 2013). The move towards more advanced service offerings also follows a general trend embedded in what is, in academia, labelled 'the service-dominant logic of the firm' (c.f. Oliva and Kallenberg, 2003). In essence, the service-dominant logic means a view on value creation built on service provision rather than goods production. Instead of having efficient production and distribution of tangible goods in focus as a means to create value, the servicedominant logic advocates value to be defined based on the value-in-use. The value is hence to be co-created with the customers. The creation of services requires specialised competences, typically knowledge and skills, where resources such as knowledge by the sales personnel are exploited in such a way that customer value is created (Lusch et al., 2008).

\section{Local presence}

Despite the development toward a service-dominant logic of the firm, the importance of local presence and understanding of local conditions have in recent years been downplayed in favour of centralisation as a means to create economies of scale (Pil and Holweg, 2003). In terms of resources and capabilities, having economies of scale and scope in purchasing and logistics seem to overrule capabilities related to local presence and management of local customer relationships. In contrast to the mega-retailers, the 
purchasing groups must consider - and accept - the local store owners as a factor that drives part of the strategic development of the supply chain. Whereas a strong centralised purchasing and logistics organisation is followed by one or a few highly standardised store concepts at a typical mega-retailer, the case companies' centralised purchasing and logistics organisations are followed by individual stores with a great variety of store concepts. This independence enables great adjustments to local demands in terms of product range, services, and marketing campaigns. The purchasing group concept emphasises the development of deep and strong relationships with the store owners and ultimately with the customers. From a resource-based view, similar to as was argued above, this requires a strong local presence as well as skilled personnel to manage the relationships with the customers. Overall, the case studies provide clear examples of when local attendance in local companies may overrule the search for economies of scale and scope, and be the foundation for a company's strategy (Pil and Holweg, 2003). We therefore propose:

Proposition 2: Retail purchasing groups allow retailers in their network to focus on developing an in-depth understanding of local conditions and a capability for strong customer relational behaviour.

From a TCE perspective the supply chain structure of a purchasing group represents an alternative way forward (compared to the mega-retailers) when creating supply chain efficiencies. The asset specific investments involved in the development of a purchasing group help to reduce uncertainty and increase frequency of transactions, factors that should lead to an overall reduction in transaction costs (Williamson, 1985). However, purchasing groups not only enable the reduction of transaction costs, but also provide 
the possibility of overriding cost focused behaviour in favour of a service-dominant logic aimed at delivering value in-use (Lusch et al., 2008), through the creation of relational resource's with customers (Dyer and Singh, 1998; McIvor, 2009).

\section{Entrepreneurship and innovation}

As discussed above, the cases show that rapid and effective response to customer demand may be facilitated by small-scale independent stores. Both groups clearly state the importance of rapid response and the ability to adjust to local demands as key competitive advantages. Instead of a store manager with little or no possibilities to influence design, advertising, pricing or product range, the stores in a purchasing group are all managed as individual companies, with full insight and responsibility for the local development. The decentralised management and owner structure gives the stores strong incitements to develop and prosper. As pointed out by several of the interviewees, although a store manager in a mega-retailer chain can receive incitements in terms of e.g. bonuses, the store owners in a retail purchasing group are even more dependent on the store. Often with family-owned stores, the store owners are willing to work very hard for their store and company, and thus are described as entrepreneurial, with a genuine interest in the products they are selling.

Retail purchasing groups have a better opportunity to align their strategies because store owners can keep their ear close to the ground and be responsive to changes in market conditions. However, this goes beyond simple strategic alignment, as the decentralised structure allows them to explore and test new strategies on a smaller scale. At a group level the store managers become a major driving force for entrepreneurship and innovation in the company as a whole, and thus the usual top- 
down strategy formation process is combined with a relatively strong bottom-up process.

Proposition 3: Retail purchasing groups allow entrepreneurial strengths and innovations to be incorporated in the supply chain.

Small-scale exploration, which is a clear feature of purchasing groups, has been highlighted by Pil and Holweg (2003) as a driver of innovation. The structure or retail purchasing groups provides them with the dynamic capabilities (Teece et al., 1997) to test new ideas and explore new opportunities in a small scale. The approach followed by these groups is also consistent with Bartlett and Ghoshal (2002) view of building strategy from the bottom-up and relying on human resources as the key to innovation and competitive advantage.

\section{Conclusion, limitations and further research}

Although purchasing groups have existed a long time in business, it has been little researched (Essig, 2000; Tella and Virolainen, 2005). The existence of autonomous local store owners could be perceived as an inhibitor to collaboration and smooth operations in the supply chain. For practitioners it is vital to understand the peculiarities and specific characteristics of retail purchasing groups and, based on that understanding, make a comprehensive analysis of their strengths and weaknesses. Instead of just imitating the dominant and successful mega-retailers, retail purchasing groups must take advantage of their external collaboration and small-scale operations. This research concludes three areas where advantages vis-à-vis mega-retailers can be identified: service-based competition in an industry otherwise focused on cost leadership, in-depth understanding of local conditions and presence, and the ability to incorporate 
entrepreneurial strengths and innovations in the supply chain. These advantages are achieved through stronger external relations downstream in the supply chain, rather than through vertical integration.

From a theoretical point of view, this research addresses an example where large-scale, highly centralised organisations building on vertical integration are not always preferable. Building on TCE and RBV, we argue that external demands and requirements can be taken more "seriously" than internal ones, which may result in more intense collaboration and integration in the supply chain. Mena et al. (2009) suggest that when discussing relationships in a supply chain, a distinction should be made between governance (referring to ownership and control) on the one hand, and collaboration (referring to the alignment of objectives) on the other. This distinction makes it possible to argue that collaboration may be a facilitator for a high degree of integration and, in turn, a smooth running, efficient supply chain. However, it is not necessary to have a centralised governance structure.

Given the exploratory nature of our approach, the research suffers from some limitations and the findings need further confirmation and development. In particular, four limitations need to be addressed in the future. First, the retail industry consists of a great variety of sectors with different business logics, for instance different product life cycles, a varying degree of competition, importance of services, and supplier characteristics. The inclusion of cases from other sectors would therefore complement the study at hand. Second, the wide purchasing group definition includes several opportunities for legal ownership structures and a more in-depth understanding for how legal structures may influence the performance of the purchasing group may be an interesting future research area. 
Third, the case studies presented in this research are limited to Swedish retail purchasing groups, operating only in the Swedish market. Although there is increasingly strong competition from multinational mega-retailers and the importance of country borders are diminishing, the Swedish market may still be somewhat protected due to its relatively small size. Similar case studies from other countries would therefore be a valuable complement to this study. Fourth, in addition to more case studies, the findings could also be verified and tested through quantitative studies. An interesting future research avenue for all the limitations would be a contingency approach as a means to advance theory.

This exploratory research has shown that under certain market conditions, a decentralised supply chain, which relies on collaborative external relationships, can provide a competitive alternative to a more traditional centralised structure. This can serve as a stepping stone for further research into alternative governance structures for effective supply chain management.

\section{References}

Abrahamsson, M. and J. Rehme. 2010. "The role of logistics in retailers' corporate strategy - A driver for growth and customer value.” Supply Chain Forum: An International Journal 11 (4): 14-23.

Anderson, J.C. and J.A. Narus. 1991. "Partnering as a focused market strategy." California Management Review 33 (3):95-113.

Ashenbaum, B., A. Maltz, L. Ellram and M.A. Barratt. 2009. “Organizational alignment and supply chain governance: Introduction and construct validation." The International Journal of Logistics Management 20 (2): 169-186.

Barney, J.B., 1991. "Firm resources and sustained competitive advantage". Journal of Management 17 (1): 99-120. 
Barney, J. and D. Clark. 2007. Resource-Based Theory: Creating and Sustaining Competitive Advantage. Oxford, Oxford University Press

Barratt, M. and A. Oliveira. 2001. "Exploring the experiences of collaborative planning initiatives." International Journal of Physical Distribution \& Logistics Management 31 (4): 266-289.

Bartlett, C. and S. Ghoshal. 2002. "Building Competitive Advantage Through People." MIT Sloan Management Review 43: 34-41.

Chandler, A., D. and T. Hikino. 1990. Scale and scope: the dynamics of industrial capitalism. Cambridge, Mass. Belknap Press, ISBN 0-674-78994-6

Chen, H., P. Daugherty, and A. Roath. 2009. "Defining and operationalizing supply chain process integration.” Journal of Business Logistics 30 (1): 63-84.

Chen, R. and P. Roma. 2010. "Group buying of competing retailers". Production and Operations Management 20 (2): 181-197.

Chow, G., T. Heaver, and L. Henriksson. 1995. "Strategy, Structure and Performance: A Framework for Logistics Research.” Logistics and Transportation Review 31 (4): 285-309.

Coase, R., 1937. “The Nature of the Firm”, Economica, New Series, 4(16), 386-405.

Combs, J.G., Ketchen, D.J., 1999. "Explaining inter-firm cooperation and performance: toward a reconciliation of predictions from the resource-based view and organizational economics”. Strategic Management Journal 20 (9): 867-888.

Conner, K.R., 1991. "A historical comparison of resource-based theory and five schools of thought within industrial organization economics: do we have a new theory of the firm?" Journal of Management 17 (1): 121-154.

Dubois, A. and L.E. Gadde. 2002. "Systematic combining: An abductive approach to case research.” Journal of Business Research 55 (7): 553-560.

Dyer, J.H. and H. Singh. 1998. "The relational view: cooperative strategy and sources of interorganizational competitive advantage.” Academy of Management Review 23(4): 660-679.

Eisenhardt, K. 1989. "Building theories from case study research.” The Academy of Management Review 14 (4): 532-550.

Eisenhardt, K. and M. Graebner. 2007. "Theory Building From Cases: Opportunities and Challenges." Academy of Management Journal 50 (1): 25-32.

Ellram, L.M. 1996. "The use of the case study method in logistics research." Journal of Business Logistics 17 (2): 93-138. 
Essig, M. 2000. "Purchasing consortia as symbiotic relationships: Developing the concept of 'consortium sourcing'." European Journal of Purchasing \& Supply Management 6 (1): 13-22.

Fawcett, S.E. and G.M. Magnan. 2001. Achieving World-Class Supply Chain Alignment: Benefits, Barriers, and Bridges. Center For Advanced Purchasing Studies. ISBN 0-945968-50-7

Ganesan, S., M. George, S. Jap, R.W. Palmatier, and B. Weitz. 2009. "Supply chain management and retailer performance: emerging trends, issues, and implications for research and practice." Journal of Retailing 85 (1): 84-94.

Goldhar, J., D. and M. Jelinek. 1983. "Plan for economies of scope.” Harvard Business Review 61 (6): 141-148.

Goshal, S., Moran, P., 1996. "Bad for Practice: A critique of Transaction Cost Theory". Academy of Management Review 21 (1), 13-47.

Gibbert, M., W. Ruigrok, and B. Wicki. 2008. "What passes as a rigorous case study?" Strategic Management Journal 29 (13): 1465-1474.

Hernandez-Espallardo, M. and M. Navarro-Bailon. 2009. “Accessing retailer equity through integration in retailers' buying groups." International Journal of Retail \& Distribution Management 37(1): 43-62.

Hernandez-Espallardo, M. 2006. "Interfirm strategic integration in retailer buying groups: Antecedents and consequences on the retailer's economic satisfaction." International Review of Retail, Distribution and Consumer Research 16 (1): 6991.

Humphries, A.S. and R.D. Wilding. 2004. "Long Term Collaborative Business Relationships: The Impact of Trust and C3 Behaviour.” Journal of Marketing Management 20: 1107-1122.

Holweg, M., S. Disney, J. Holmström, and J. Småros. 2005. "Supply chain collaboration: Making sense of the strategy continuum." European Management Journal 23 (2): 170-181.

Jacobides, M.G., Winter, S.G., 2005. "The co-evolution of capabilities and transaction costs: explaining the institutional structure of production". Strategic Management Journal 26 (5): 395-413.

Lawrence, P.R. and J.W. Lorsch. 1967. Organization and Environment: Managing Differentiation and Integration. Boston, MA: Harvard University. 
Lusch, R.F., S.L. Vargo, and G. Wessels. 2008. "Toward a conceptual foundation for service science: Contributions from service-dominant logic.” IBM Systems Journal 47 (1): 5-14.

Madhok, A., 2002. "Reassessing the fundamentals and beyond: Ronald Coase, the transaction cost and resource-based theories of the firm and institutional structure of production”. Strategic Management Journal 23 (6): 535-550.

McIvor, R., 2009. "How the transaction cost and resource-based theories of the firm inform outsourcing evaluation". Journal of Operations Management 27 (1): 4563.

Mena, C., A. Humphries, and R. Wilding. 2009. "A comparison of inter- and intraorganizational relationships.” International Journal of Physical Distribution and Logistics Management 39 (9): 762-784.

Mentzer, J.T., W. DeWitt, J.S. Keebler, S. Min, N.W. Nix, C.D. Smith and A.G. Zacharia. 2001. "Defining Supply Chain Management." Journal of Business Logistics 22 (2): 1-25.

Nollet, J. and M. Beaulieu. 2005. "Should an organisation join a purchasing group?" Supply Chain Management: An International Journal 10 (1): 11-17.

Oliva, R. and R. Kallenberg. 2003. "Managing the transition from products to services." International Journal of Service Industry Management 14 (2): 160-172.

Pagell, M. 2004. "Understanding the factors that enable and inhibit the integration of Operations, Purchasing and Logistics." Journal of Operations Management 22 (5): 459-487.

Panzar, J, C. and R. D. Willig. 1981. "Economies of Scope.” AEA Papers and Proceedings 71 (2): 268-272.

Perrow, C., 1986. “Complex Organizations”, Random House, New York.

Peteraf, M.A., 1993. "The cornerstones of competitive advantage: a resource-based view”. Strategic Management Journal 14 (3): 179-191.

Pil, F. and M. Holweg. 2003. "Exploring Scale: The advantages of thinking small." MIT Sloan Management Review, 44: 33-39

Porter, M., 1985. Competitive advantage: Creating and sustaining superior performance. New York: Free Press. ISBN 0684841460.

Renko, S. and D. Ficko. 2010. "New logistics technologies in improving customer value in retailing service.” Journal of Retailing and Consumer Services 17 (3): 216223. 
Sampson, S. 2008. "Category killers and big-box retailing: their historical impact on retailing in the USA." International Journal of Retail and Distribution Management 36 (1): 17-31.

Sandberg, E. 2013. "Understanding logistics-based competition in retail - A business model approach." International Journal of Retail and Distribution Management 41 (3): 176-188.

Schotanus, F. and J. Telgen. 2007. "Developing a typology of organisational forms of cooperative purchasing." Journal of Purchasing and Supply Management 13: 53-68.

Simon, H. A., 1991. “Organizations and markets”. Journal of Economic Perspectives, 5(2): 25-44.

Stuart, I., D. McCutcheon, R. Handfield, R. McLachlin and D. Samson. 2002. "Effective case research in operations management: a process perspective." Journal of Operations Management 20: 419-433.

Tella, E. and V-M. Virolainen. 2005. "Motives behind purchasing consortia." International Journal of Production Economics 93-94: 161-168.

Teece, D.J., G. Pisano, and A. Shuen. 1997. "Dynamic capabilities and strategic management.”. Strategic Management Journal 18(7): 509-533.

Vivek, S., Banwet, D., Shankar, R., 2008. “Analysis of interactions among core, transaction and relationship-specific investments". Journal of Operations Management 26 (2): 180-197.

Walker, H., M. Essig, F. Schotanus, and T. Kivisto. 2006. Co-operative purchasing in the public sector, In: Public Procurement; International Cases and Commentary for Policy Reform, (Eds). Knight, L.A., Harland, C.M., Telgen, J., Callender, G., Thai, K.V. and McKen, K.E. Routledge, 325-342, ISBN 978-0-415-39404-8

Wang, E. and H.-L.Wei. 2007. "Interorganisational governance value creation: Coordinating for Information Visibility and Flexibility in supply chains." Decision Sciences 38 (4): 647-674.

Wernerfelt, B., 1984. “A resource-based view of the firm.” Strategic Management Journal, 5 (2): 171-180.

Williamson, O.E., 1975. "Markets \& Hierarchies: Analysis \& Anti-trust Implications", The Free Press, New York, NY.

Williamson, O.E., 1979. "Transaction-cost economics: the governance of contractual relations". Journal of Law \& Economics, 22 (2): 233-61. 
Williamson, O.E., 1985. The Economic Institutions of Capitalism, The Free Press, New York.

Williamson, O.E., 2008. "Outsourcing: transaction cost economics and supply chain management". Journal of Supply Chain Management, 44(2), 5-16.

Yin, R.K., 2003. Case Study Research: Design and Methods. Sage Publications.

Zentes, J. and B. Swoboda. 2000. "Allied groups on the road to complex networks." Technology in Society 22: 133-150. 


\section{Appendix A: Interview Guide}

\section{General information about the group}

○ History - why was the purchasing group founded?

○ Owners

- About the members and their businesses

○ Present overall group strategy

\section{Organization}

- What functions are included in the collaboration? (purchasing, marketing, logistics, etc?)

○ Formal-informal organization

- Responsibility interfaces between the group and the member store/company. (Centralization vs decentralization)

\section{Logistics operations and organization}

- The flow of goods, including the central warehouse

○ Degree of centralization in the flow of goods

○ Transportation

\section{Advantages and disadvantages of a purchasing group concept}

○ Purchasing - Product range - Distribution - Marketing

○ Specific challenges

\section{Future development of the group}

- The purpose of the purchasing group - now and then

○ Trends influencing the group

○ Future plans and strategy (purchasing, product range, logistics, etc.) 
Tables

Table 1: Definitions of purchasing groups and related terms

\begin{tabular}{|c|c|c|}
\hline Term & Definition & Author(s) \\
\hline $\begin{array}{l}\text { Co-operative } \\
\text { purchasing }\end{array}$ & $\begin{array}{l}\text { "the pooling of purchasing related information, } \\
\text { expertise, resources or volumes between } \\
\text { independent organizations to improve their } \\
\text { performances." }\end{array}$ & $\begin{array}{l}\text { Walker et al., 2006, p. } \\
576\end{array}$ \\
\hline $\begin{array}{l}\text { Cooperative } \\
\text { purchasing }\end{array}$ & $\begin{array}{l}\text { "the cooperation between two or more } \\
\text { organizations in a purchasing group in one or } \\
\text { more steps of the purchasing process by sharing } \\
\text { and/or bundling their purchasing volumes, } \\
\text { information, and/or resources. A purchasing } \\
\text { group is defined as an organization in which } \\
\text { cooperative purchasing processes take place." }\end{array}$ & $\begin{array}{l}\text { Schotanus and Telgen, } \\
2007 \text {, p. } 53\end{array}$ \\
\hline $\begin{array}{l}\text { Consortium } \\
\text { purchasing }\end{array}$ & $\begin{array}{l}\text { "horizontal cooperation between independent } \\
\text { organizations that pool their purchases in order } \\
\text { to achieve various benefits." }\end{array}$ & $\begin{array}{l}\text { Tella and Virolainen, } \\
2005, \text { p. } 162\end{array}$ \\
\hline $\begin{array}{l}\text { Purchasing } \\
\text { group }\end{array}$ & $\begin{array}{l}\text { "a formal or virtual structure that facilitates the } \\
\text { consolidation of purchases for many } \\
\text { organizations. Consolidation is a procurement } \\
\text { practice used to transfer to a central entity } \\
\text { activities such as: bidding, supplier evaluation, } \\
\text { negotiation, and contract management." }\end{array}$ & $\begin{array}{l}\text { Nollet and Beaulieu, } \\
2005 \text {, p. } 12\end{array}$ \\
\hline
\end{tabular}




\begin{tabular}{|l|l|l|}
\hline Buying groups & "Conceptually, buying groups are horizontal & Hernandez-Espallardo, \\
& $\begin{array}{l}\text { alliances or associations of retailers to achieve } \\
\text { advantages in supplying." }\end{array}$ & 2006, p. 70 \\
\hline
\end{tabular}

Table 2: Titles of interviewees at the case companies

\begin{tabular}{|l|l|}
\hline Group A & Group B \\
\hline Chain Manager X & CFO \\
\hline Logistics Manager & CEO \\
\hline Chain Manager Y & Purchasing Manager \\
\hline Purchasing Manager & Purchasing Manager \\
\hline
\end{tabular}

